\title{
Direct Persecution of Crowned Eagles (Buteogallus coronatus) in Argentina: A New Call for Their Conservation
}

\author{
Author(s): Facundo BarbarAndrés Capdevielle and Manuel Encabo
}

Source: Journal of Raptor Research, 50(1):115-120.

Published By: The Raptor Research Foundation

DOI: http://dx.doi.org/10.3356/rapt-50-01-115-120.1

URL: http://www.bioone.org/doi/full/10.3356/rapt-50-01-115-120.1

BioOne (www.bioone.org) is a nonprofit, online aggregation of core research in the biological, ecological, and environmental sciences. BioOne provides a sustainable online platform for over 170 journals and books published by nonprofit societies, associations, museums, institutions, and presses.

Your use of this PDF, the BioOne Web site, and all posted and associated content indicates your acceptance of BioOne's Terms of Use, available at www.bioone.org/ page/terms_of_use.

Usage of BioOne content is strictly limited to personal, educational, and noncommercial use. Commercial inquiries or rights and permissions requests should be directed to the individual publisher as copyright holder. 


\title{
SHORT COMMUnications
}

J. Raptor Res. 50(1):115-120

(C) 2016 The Raptor Research Foundation, Inc.

\section{Direct Persecution of Crowned Eagles (Buteogallus Coronatus) in Argentina: A NEW CALl FOR THEIR CONSERVATION}

\author{
FACUNDO BARBAR ${ }^{1}$ \\ Laboratorio Ecotono INIBIOMA (CONICET-Universidad Nacional del Comahue), San Carlos de Bariloche, Río Negro, \\ Argentina
}

\author{
Andrés CaPdeVielle AND Manuel ENCABO \\ Jardín Zoológico de la Ciudad de Buenos Aires - PCRAR, Programa de Conservación y Rescate de Aves Rapaces, \\ Ciudad Autónoma de Buenos Aires, Argentina \\ and \\ Fundación Caburé-í, Ciudad Autónoma de Buenos Aires, Argentina
}

KeY WORDS: Crowned Eagle; Buteogallus coronatus; Argentina; endangered species; persecution; population.

The Crowned Eagle (Buteogallus coronatus) is a large Neotropical raptor, widely distributed across open dry forests and savannas in South America, including southeastern and central Brazil, Paraguay, Bolivia, and Argentina (Ferguson-Lees and Christie 2001). Despite its large distribution range, this eagle occurs presumably in low densities, with an estimated maximum population of 1500 individuals. Therefore, this species is categorized as Endangered on the IUCN red list (BirdLife International 2012). Adults can hold a territory of more than $600 \mathrm{~km}^{2}$ (Rodríguez et al. 2011), and juveniles can cover larger areas during their natal dispersal (up to $12,000 \mathrm{~km}^{2}$ in a 3-yr dispersal period; Mojica et al. 2013, Urios et al. 2014). Pressure due to habitat degradation appears to be the major threat in the northeastern part of its distribution (i.e., Cerrado in Brazil; BirdLife International 2012, Granzinolli et al. 2013), whereas in other areas, nonnatural mortality such as collisions with human constructions (e.g., power lines and stock water tanks) and direct persecution are the identified threats (Sarasola and Maceda 2006, Capdevielle and Sarasola 2011, Galmes et al. 2013, Mojica et al. 2013).

Here, we present the cases of direct human persecution on Crowned Eagles in Argentina documented over the 15 yr of the "Crowned Eagle Project" in the Program of Conservation and Rescue of Birds of Prey (hereafter "PCRAR" for its Spanish initials) which functions mainly as a rehabilitation center, and we supplement our data with a review of the available literature. Our goal was to compile all information about the persecution suffered by this eagle species in Argentina.

${ }^{1}$ Present address: Quintral 1250, FRF 8400 Bariloche, Río Negro, Argentina; email address: facundo.barbar@gmail.com

\section{METHODS}

We reviewed every case recorded by the PCRAR during its existence, from 1999 to 2014, recording the following information for injured eagles: (1) date of arrival at the rehabilitation center; (2) origin (i.e., province); (3) age; (4) sex; (5) cause of injuries; and (6) source (i.e., the institution that delivered the individual (see Appendix). We also performed informal surveys about this matter of the local people, rangers, and wildlife inspectors, every time we were in the field releasing a rehabilitated individual, to learn if there were any unreported cases of persecution. If we confirmed such a case, we recorded the same information (when possible) recorded for each eagle admitted to the PCRAR.

Additionally, we reviewed all the available literature on the species, to search for published cases of direct persecution on this species. For this, we used Scopus, Google Scholar, Google, SciELO, and SORA search engines and local journals of ornithology (e.g., Nuestras Aves) to complete the search. We reviewed each article for specific cases of persecution, and obtained, when possible, the same information gathered for the PCRAR records.

\section{RESULTS}

We found 83 cases of direct persecution over the period 1980-2014 in Argentina. The cases were recorded in 13 of the 16 provinces of Argentina where the species occurs (Fig. 1). Thirty-eight eagles were admitted or reported to the PCRAR, and the rest of the cases were drawn from the published accounts. Most of the records were from the last $15 \mathrm{yr}$, with ca. $10 \%$ of the cases prior to 1999 and ca. $90 \%$ distributed between known and unknown dates (but presumably after 1999; Appendix). Moreover, there was a peak of cases during 2000-2004, which slowly decreased to the 


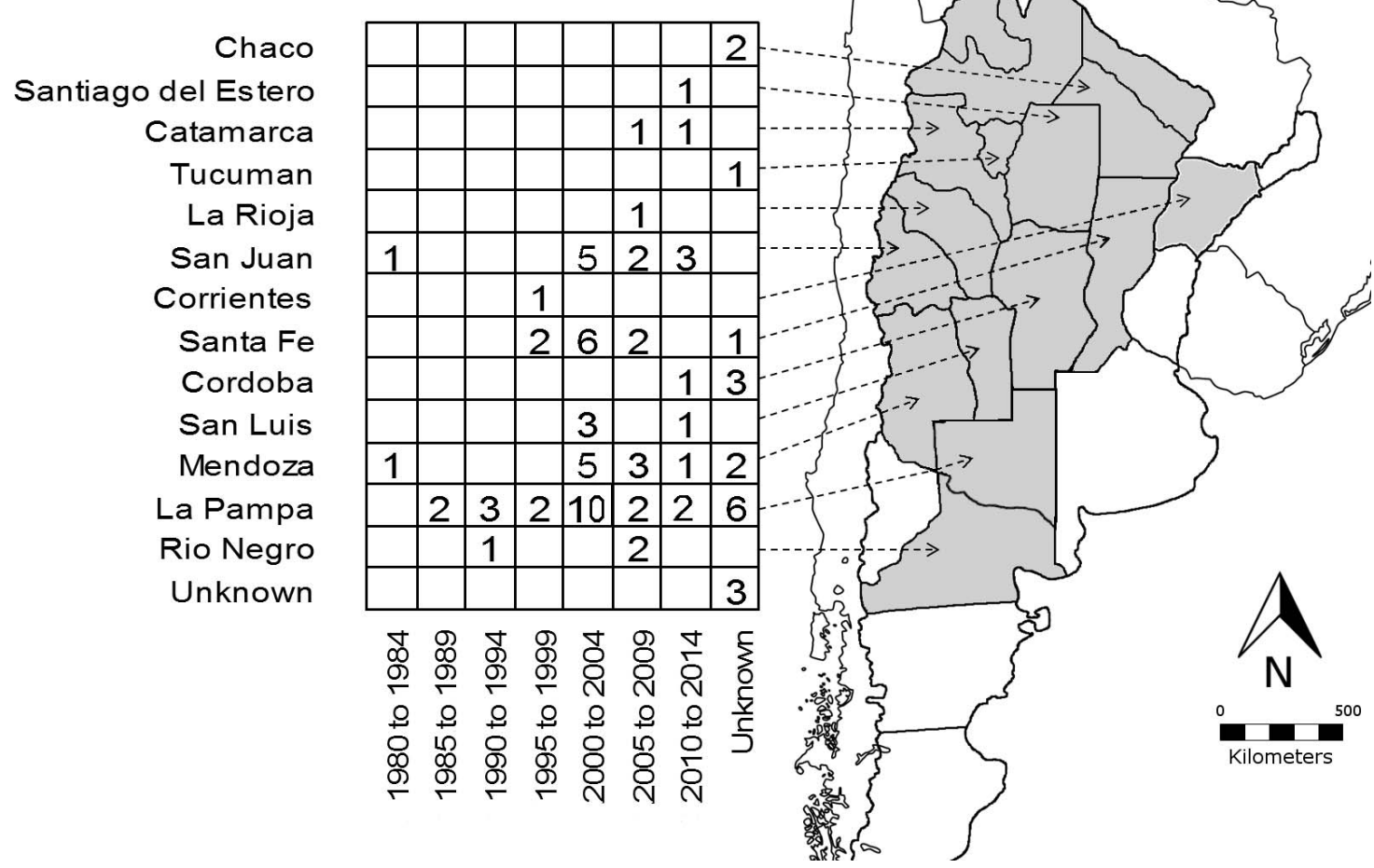

Figure 1. The distribution of cases of direct persecution on Crowned Eagles (Buteogallus coronatus) in Argentina from 1980 to 2014. Data taken from PCRAR records (this study), De Lucca 1992, De Lucca 1993, Yzurieta 1995, Maceda et al. 2003, Pautasso et al. 2003, Pereyra-Lobos 2004, Sarasola and Maceda 2006, Chébez 2008, Rodríguez et al. 2009, Pautasso 2011, Fandiño and Pautasso 2013, Mojica et al. 2013. The names of each province are shown on the horizontal rows, and dashed arrows indicate the locations of each province on the map. Vertical rows represent the 5-yr blocks into which we divided the 1980-2014 study period. The distribution of the species throughout the Argentine provinces is shown by gray shading.

present (Fig. 1, Appendix). La Pampa - in the southern tip of the distribution - was the area with the most cases $(n=27)$, while Corrientes, Santiago del Estero, Tucumán, and La Rioja - all toward the north - had only one record each.

\section{DISCUSSION}

Our investigation suggests that direct persecution is an important threat to Crowned Eagles in Argentina. This persecution is generally associated with the belief that Crowned Eagles prey on livestock (Giacomelli 1923), although these do not actually make up a large part of the species' diet, composing only $0.17 \%$ in one study (Sarasola et al. 2010) and not recorded in two other studies (Maceda et al. 2003, Pereyra-Lobos et al. 2011).

Most of the cases of persecution in our study occurred in the southern and western portions of the eagle distribution in Argentina. This may be related to the fact that in this region cattle ranching is extensive; the forest here is maintained as a source of refuge and food supply for the cattle (e.g., Menéndez 2005, 2007), which allows the eagles to stay in their same habitat, but this proximity also facilitates the human-eagle conflict. Conversely, in northern Argentina, natural forests have been largely replaced by crops (soybean and cotton plantations, Bertonatti and Corcuera 2000), relegating the eagles to more pristine environments where interactions with humans are fewer. However, our data do not allow us to discern whether this skew toward the south and west was related to the greater number of people studying the species there or to the potential human-eagle conflicts in each region.

We detected a peak of persecution early in the 2000s. This is likely related to the increasing number of people studying the Crowned Eagle in the field and elsewhere (Capdevielle et al. 2010), rather than a real increase in persecution. The more recent decrease in the number of killed, injured, or captured eagles might be due to conservation actions to prevent persecution (i.e., the presence of more researchers in the field, educational campaigns, and media 
attention) that may have played a major role in changing the local perception of the eagle. However, despite these efforts, eagles are still received at the rehabilitation center and found dead in the field (F. Barbar unpubl. data).

Collaboration between conservation groups has led Argentina to be the first and only country to create a national action plan for the conservation of the Crowned Eagle (see Capdevielle et al. 2010, Capdevielle and Sarasola 2011). Although we here quantified direct persecution country-wide, we do not know how this persecution affects the population. Moreover, other threats are also important, including power lines, stock water tanks, and habitat degradation, and little is known about the real effects of these. We encourage conservation institutions, both governmental and NGOs, to participate and support existing projects, and to generate new studies and conservation initiatives. We need to improve our knowledge about this species' biology and needs, recognize threats in different regions, educate local people in conservation issues, and propose effective protection laws, to reverse the current status of one of the most endangered raptors in the world.

\section{PERSECUCIÓN DIRECTA DE BUTEOGALLUS CORONA-} TUS EN ARGENTINA: UN NUEVO LLAMADO PARA SU CONSERVACIÓN

Resumen.-Buteogallus coronatus es un ave rapaz de gran tamaño y una de las especies de rapaces más amenazadas en el mundo, con una población máxima estimada de 1500 individuos. Las principales amenazas identificadas para esta especie son la pérdida y degradación de su hábitat y la mortalidad no natural por persecución directa y colisiones con infraestructuras humanas. Reportamos casos de persecución directa sobre esta especie en Argentina. Compilamos toda la información publicada disponible y también los casos de aves entregadas al centro de rehabilitación del Programa de Conservación y Rescate de Aves de Presa del Zoológico de Buenos Aires. Durante el periodo comprendido entre 1980 y 2014, encontramos 83 casos provenientes de casi todas las provincias argentinas en la que el águila está presente. Nuestros resultados evidencian que probablemente la persecución directa es una causa de mortalidad importante para las águilas en Argentina.

\section{[Traducción del equipo editorial]}

\section{ACKNOWLEDGMENTS}

We thank A. Onetto, G. Terni, G. Porini, H. Ibáñez, H. Orestes Asensio, I. Kasulin, L. Denápole, M. Suárez, M. Jordan, M. Ayarragaray, P. Juliá, and P. Luna, for their participation in the treatment and study of eagles brought to the PCRAR. We greatly appreciate the field assistance provided by A. Gonzalez, A. Quaglia, D. Ortíz, E. Fra, G. Wiemeyer, J. Anfuso, M. Ariza, R. Rodríguez, N. Lois, and $\mathrm{U}$. Balza in the final stages of the rehabilitation process. We also thank E. Pescetti, G. Aprile, H. López, Jofré and San Martín families, J.H. Sarasola, J.C. Chébez, L. Muñoz,
M. Muñoz, M. Galmes, and R. Pereyra-Lobos, for providing useful information about old and new cases of persecution in Argentina. We thank C. Bertonatti, E. Laugier, O. Guaita, the Buenos Aires Zoo, Aves Argentinas, Fundación Bioandina, and ZCOG (Zoo Conservation Outreach Group) for supporting this project, especially in the early years. We appreciate the suggestions to improve an earlier version of this report from S. Lambertucci, J.M. Guido, A. Quaglia, and G. Ignazi. We also thank the anonymous referee and the editor who revised our manuscript. Finally, we especially thank the volunteers of the PCRAR for their active participation in the last 15 years.

\section{LITERATURE CiTED}

BertonAtTi, C. AND J. CORCUERA. 2000. Situación ambiental Argentina 2000. Fundación Vida Silvestre Argentina, Buenos Aires, Argentina

BirdLife InTERnAtional. 2012. Buteogallus coronatus. The IUCN Red List of threatened species. Version 2014.2. www.iucnredlist.org (last accessed 2 August 2014).

Capdevielle, A., E. De lucca, M. Encabo, M. Galmes, P. Grilli, F. Martínez, N. Lois, D. Ortíz, H. Paulini, R. Pereyra lobos, E. Pescetti, A. Quaglia, J. Raggio, M. SaGgese, J. SARAsola, G. Wiemeyer, and G. ZorZIN. 2010. Plan de acción para la conservación del águila coronada (Harpyhaliaetus coronatus) en la Argentina. http://avesargentinas.org.ar/12/03-aves_en_peligro_ aguila_coronada.php (last accessed 2 August 2014).

- AND J.H. SARASOLA. 2011. I Revisión del plan de acción para la conservación del águila coronada (Harpyhaliaetus coronatus) en la Argentina. In XIV reunión Argentina de ornitología. Formosa, Argentina. http:// avesargentinas.org.ar/12/conservacion/amenazadas/ aguila_coronada/taller4.pdf (last accessed 17 November 2015).

CHÉBEZ, J.C. 2008. Los que se van 2: especies argentinas en peligro: Aves. Albatroz, Buenos Aires, Argentina.

DE LUCCA, E.R. 1992. El águila coronada Harpyhaliaetus coronatus en San Juan. Nuestras Aves 26:25.

1993. Águila coronada. Nuestras Aves 29:14-17.

FANDiÑO, B. AND A.A. PAUTASSO. 2013. Distribución, historia natural y conservación de Harpyhaliaetus coronatus (aves: accipitridae) en el centro-este de Argentina. Natura Neotropicalis 1:41-55.

Ferguson-LeEs, J. AND D.A. Christie. 2001. Raptors of the world. Houghton Mifflin Company, New York, NY U.S.A.

Galmes, M.A., J.H. SARAsola, AND J.M. GRANDE. 2013. Conservation program of Crowned Solitary Eagle (Harpyhaliaetus coronatus) in the Province of La Pampa, Argentina. Spizaetus 16:21-25.

GiACOMELLI, E. 1923. Catálogo sistemático de las aves útiles y nocivas de la provincia de La Rioja. Hornero 3:66-84.

Granzinolli, M.A.M., R.J.G. Pereira, and J.C.M. Junior. 2013. The Crowned Solitary-eagle Harpyhaliaetus coronatus (Accipitridae) in the cerrado of Estação Ecológica de Itirapina, southeast Brazil. Revista Brasileira de Ornitologia 14:429-432. 
Maceda, J.J., J.H. Sarasola, and M.E.M. Pessino. 2003. Presas consumidas por el águila coronada (Harpyhaliaetus coronatus) en el límite sur de su rango de distribución en Argentina. Ornitología Neotropical 14:419-422.

MENÉNDEZ, J.L. 2005. Primer inventario nacional de bosques nativos. Informe Nacional Diciembre 2005. Dirección Nacional de Bosques, Buenos Aires, Argentina.

2007. Primer inventario nacional de bosques nativos. Segunda etapa, inventario de campo de la región del Espinal: distritos del caldén y ñandubay. Dirección Nacional de Bosques, Buenos Aires, Argentina.

Mojica, E.K., M.A. Galmes, B.J. PaXton, B.D. Watts, J.M. GRANDE, AND J.H. SARASOLA. 2013. Post-dispersal movements and juvenile survival of the Solitary Crowned Eagle (Harpyhaliaetus coronatus) in central Argentina. Page 114 in M. Saggese [ED.], First Worldwide Raptor Conference, Bariloche, Argentina.

Pautasso, A.A. 2011. La fauna y su conservación en los Bajos Submeridionales. Serie naturaleza, Conservación y Sociedad No. 5. Santa Fe, Argentina.

- M.R. De La Peña, and J.M. Mastropaolo. 2003. Nuevos registros del águila coronada (Harpyhaliaetus coronatus) para la provincia de Santa Fé, Argentina. Nuestras Aves 46:29-32.

PEREYRA-Lobos, R. 2004. Nuevos registros de águila coronada (Harpyhaliaetus coronatus) para la provincia de Mendoza, Argentina. Nuestras Aves 47:26-27.

-, F.J. Santander, S.A. Orellana, P.A. Ramírez, L. MuÑoz, AND D.F. BELlón. 2011. Diet of the Crowned Eagle (Harpyhaliaetus coronatus) during the breeding season in the Monte desert, Mendoza, Argentina. Journal of Raptor Research 45:180-183.
Rodríguez, M.S., N.A. Lois, F. Barbar, A. Quaglia, L. Biondi, U. BALZA, G.M. Wiemeyer, and A. CAPDEVIELle. 2011. Home-range y movimientos estacionales de un ejemplar de Águila Coronada (Harpyhaliaetus coronatus) en Catamarca. Page 116 in XIV reunión Argentina de ornitología. Formosa, Argentina.

Rodríguez Groves, V., A. Pautasso, P. Preliasco, M.V. DEL SASTRE, AND F. MiÑARro. 2009. Relevamiento ambiental de la estancia Isleta Linda, Provincia de Santa Fe. Programas Refugios de Vida Silvestre, Fundación Vida Silvestre Argentina, Buenos Aires, Argentina.

SARASOla, J.H. And J.J. MACEDA. 2006. Past and current evidence of persecution of the endangered Crowned Eagle Harpyhaliaetus coronatus in Argentina. Oryx 40: 347-350.

— M.Á. SANTILláN, AND M.A. Galmes. 2010. Crowned Eagles rarely prey on livestock in central Argentina: persecution is not justified. Endangered Species Research 11:207-213.

Urios, V., M.P. Donat-Torres, M. Bechard, and M. FERRER. 2014. Movements of a juvenile Crowned Eagle (Harpyhaliaetus coronatus) tracked by satellite telemetry in central Argentina. Journal of Biological Research-Thessaloniki 21:12.

YZURIETA D. 1995. Manual de reconocimiento y evaluación ecológica de las aves de Córdoba. Ministerio de Agricultura, Ganadería y Recursos Renovables. Córdoba, Argentina.

Received 7 November 2014; accepted 4 June 2015 Associate Editor: Vincenzo Penteriani 
APPENDIX 1. Direct persecution of Crowned Eagles in Argentina. A: adult; SA: subadult; J: juvenile; PCRAR (Spanish intials for Program of Conservation and Rescue of Birds of Prey). Categories for type of incident match the original description of the different authors: "Trapping/captive" were those kept in captivity until found, "Trapping/killed" were those trapped for the purpose of being killed, and "Trapping" were those reported as trapped but their end was uncertain.

\begin{tabular}{|c|c|c|c|c|c|c|}
\hline DATE & AGE & SEX & TYPE OF INCIDENT & PROVINCE & SOURCE & $n$ \\
\hline Feb 2008 & A & $\mathrm{F}$ & Shooting & Catamarca & PCRAR $^{1}$ & 1 \\
\hline Sept 2011 & $\mathrm{~J}$ & $\mathrm{U}$ & Shooting & Catamarca & PCRAR $^{1}$ & 1 \\
\hline Unknown & $\mathrm{A}$ & M & Trapping/captive & Chaco & PCRAR $^{2}$ & 1 \\
\hline Unknown & A & $\mathrm{F}$ & Trapping/captive & Chaco & PCRAR $^{2}$ & 1 \\
\hline Unknown & $\mathrm{J}$ & $\mathrm{U}$ & Shooting & Córdoba & Pautasso et al. 2003a & 1 \\
\hline Unknown & $\mathrm{A}$ & M & Trapping/captive & Córdoba & PCRAR - Caburé-í Foundation & 1 \\
\hline Unknown & $\mathrm{A}$ & $\mathrm{F}$ & Trapping/captive & Córdoba & PCRAR - Caburé-í Foundation & 1 \\
\hline Sept 2014 & $\mathrm{~J}$ & $\mathrm{U}$ & Shooting & Córdoba & PCRAR $^{3}$ & 1 \\
\hline 1999 & $\mathrm{U}$ & $\mathrm{U}$ & Trapping & Corrientes & PCRAR $^{4}$ & 1 \\
\hline Unknown & $\mathrm{U}$ & $\mathrm{U}$ & Shooting/disturbance & La Pampa & Sarasola and Maceda 2006 & 3 \\
\hline Unknown & $\mathrm{U}$ & $\mathrm{U}$ & Shooting & La Pampa & Sarasola and Maceda 2006 & 1 \\
\hline Unknown & $\mathrm{J}$ & $\mathrm{U}$ & Shooting & La Pampa & Sarasola and Maceda 2006 & 1 \\
\hline Unknown & $\mathrm{J}$ & $\mathrm{U}$ & Shooting & La Pampa & Sarasola and Maceda $2006^{\mathrm{b}}$ & 1 \\
\hline July 1985 & $\mathrm{~J}$ & $\mathrm{U}$ & Shooting & La Pampa & Sarasola and Maceda 2006 & 1 \\
\hline May 1988 & $\mathrm{~J}$ & $\mathrm{U}$ & Trapping & La Pampa & Sarasola and Maceda 2006 & 1 \\
\hline 1990 & $\mathrm{~J}$ & $\mathrm{U}$ & Shooting & La Pampa & Sarasola and Maceda 2006 & 1 \\
\hline Oct 1990 & $\mathrm{~A}$ & $\mathrm{U}$ & Disturbance & La Pampa & Sarasola and Maceda 2006 & 2 \\
\hline 1996 & $\mathrm{~N}$ & $\mathrm{U}$ & Took from nest & La Pampa & PCRAR - Caburé-í Foundation & 1 \\
\hline Jan 1999 & SA & $\mathrm{U}$ & Shooting/accidental & La Pampa & Sarasola and Maceda 2006 & 1 \\
\hline 23 Jun 2000 & SA & M & Shooting & La Pampa & Sarasola and Maceda $2006^{c}$ & 1 \\
\hline May 2001 & $\mathrm{~J}$ & $\mathrm{U}$ & Shooting & La Pampa & Sarasola and Maceda 2006 & 1 \\
\hline June 2001 & $\mathrm{~J}$ & $\mathrm{U}$ & Shooting & La Pampa & Sarasola and Maceda 2006 & 1 \\
\hline 30 Jun 2001 & $\mathrm{~A}$ & M & Shooting & La Pampa & Sarasola and Maceda $2006^{c}$ & 1 \\
\hline Jan 2004 & A & $\mathrm{F}$ & Trapping & La Pampa & Sarasola and Maceda 2006 & 1 \\
\hline 1999-2004 & $\mathrm{U}$ & $\mathrm{U}$ & Shooting & La Pampa & Chébez 2008 & 5 \\
\hline May 2008 & $\mathrm{~J}$ & $\mathrm{~F}$ & Took from nest & La Pampa & PCRAR $^{5}$ & 1 \\
\hline Apr 2009 & $\mathrm{~J}$ & $\mathrm{~F}$ & Took from nest & La Pampa & PCRAR $^{5}$ & 1 \\
\hline 2011 & $\mathrm{~J}$ & $\mathrm{U}$ & Shooting & La Pampa & Mojica et al. 2013 & 1 \\
\hline 02 Nov 2014 & $\mathrm{~J}$ & M & Shooting & La Pampa & PCRAR $^{5}$ & 1 \\
\hline May 2009 & $\mathrm{~J}$ & M & Trapping & La Rioja & PCRAR $^{6}$ & 1 \\
\hline Unknown & $\mathrm{A}$ & $\mathrm{U}$ & Trapping/captive & Mendoza & $\mathrm{PCRAR}^{7}$ & 1 \\
\hline Unknown & $\mathrm{A}$ & $\mathrm{U}$ & Trapping/captive & Mendoza & PCRAR $^{7}$ & 1 \\
\hline 1980 & $\mathrm{~J}$ & $\mathrm{U}$ & Took from nest & Mendoza & PCRAR - Caburé-í Foundation & 1 \\
\hline 2000 & $\mathrm{~J}$ & $\mathrm{U}$ & Trapping/killed & Mendoza & PCRAR - Caburé-í Foundation & 1 \\
\hline 13 Sept 2002 & $\mathrm{U}$ & $\mathrm{U}$ & Shooting & Mendoza & Sarasola and Maceda $2006^{\mathrm{d}}$ & 1 \\
\hline 1999-2004 & $\mathrm{U}$ & $\mathrm{U}$ & Trapping/captive & Mendoza & PCRAR $^{7, e}$ & 1 \\
\hline 1999-2004 & $\mathrm{U}$ & $\mathrm{U}$ & Trapping/captive & Mendoza & PCRAR $^{7, \mathrm{e}}$ & 1 \\
\hline 1999-2004 & $\mathrm{U}$ & $\mathrm{U}$ & Trapping/captive & Mendoza & PCRAR $^{7, e}$ & 1 \\
\hline Mar 2005 & $\mathrm{~J}$ & $\mathrm{~F}$ & Took from nest & Mendoza & PCRAR $^{7}$ & 1 \\
\hline 2007 & $\mathrm{~J}$ & $\mathrm{U}$ & Trapping/killed & Mendoza & PCRAR & 1 \\
\hline Apr 2008 & $\mathrm{~J}$ & M & Took from nest & Mendoza & $\mathrm{PCRAR}^{7}$ & 1 \\
\hline Apr 2013 & $\mathrm{~J}$ & M & Trapping/captive & Mendoza & PCRAR $^{7}$ & 1 \\
\hline 1990 & $\mathrm{~J}$ & $\mathrm{U}$ & Took from nest & Río Negro & PCRAR - Caburé-í Foundation & 1 \\
\hline 2005 & $\mathrm{U}$ & $\mathrm{U}$ & Shooting & Río Negro & PCRAR & 1 \\
\hline 2005 & $\mathrm{~J}$ & $\mathrm{U}$ & Trapping/captive & Río Negro & PCRAR $^{8}$ & 1 \\
\hline June 1984 & $\mathrm{~J}$ & $\mathrm{U}$ & Trapping & San Juan & Sarasola and Maceda $2006^{\mathrm{f}}$ & 1 \\
\hline 1999-2004 & $\mathrm{U}$ & $\mathrm{U}$ & Trapping/captive & San Juan & Chébez 2008 & 1 \\
\hline 1999-2004 & $\mathrm{A}$ & M & Shooting & San Juan & Chébez 2008 & 1 \\
\hline 1999-2004 & A & $\mathrm{F}$ & Shooting & San Juan & Chébez 2008 & 1 \\
\hline 1999-2004 & A & $\mathrm{U}$ & Shooting & San Juan & Chébez 2008 & 1 \\
\hline
\end{tabular}


APPENDIX 1. Continued.

\begin{tabular}{|c|c|c|c|c|c|c|}
\hline DATE & AGE & SEX & TYPE OF INCIDENT & PROVINCE & SOURCE & $n$ \\
\hline 1999-2004 & $\mathrm{J}$ & $\mathrm{U}$ & Poisoned & San Juan & Chébez 2008 & 1 \\
\hline Oct 2005 & $\mathrm{~J}$ & M & Trapping/captive & San Juan & PCRAR $^{9}$ & 1 \\
\hline 2009 & $\mathrm{~J}$ & $\mathrm{U}$ & Trapping/captive & San Juan & PCRAR $^{9}$ & 1 \\
\hline June 2011 & $\mathrm{~J}$ & M & Shooting & San Juan & PCRAR $^{10}$ & 1 \\
\hline Nov 2012 & $\mathrm{~J}$ & M & Shooting & San Juan & PCRAR $^{9}$ & 1 \\
\hline Aug 2012 & $\mathrm{~J}$ & M & Took from nest & San Juan & PCRAR $^{9}$ & 1 \\
\hline Dec 2001 & $\mathrm{~J}$ & $\mathrm{~F}$ & Shooting & San Luis & PCRAR $^{11}$ & 1 \\
\hline 1999-2004 & $\mathrm{U}$ & $\mathrm{U}$ & Shooting & San Luis & Chébez 2008 & 2 \\
\hline July 2014 & SA & $\mathrm{U}$ & Shooting & San Luis & 5,11 & 1 \\
\hline 1997-2009 & $\mathrm{U}$ & $\mathrm{U}$ & Shooting & Santa Fé & Fandiño and Pautasso 2013 & 5 \\
\hline 1997-2009 & $\mathrm{J}$ & $\mathrm{U}$ & Trapping & Santa Fé & Fandiño and Pautasso 2013 & 3 \\
\hline 1997-2009 & $\mathrm{J}$ & $\mathrm{U}$ & Accidental & Santa Fé & Fandiño and Pautasso 2013 & 1 \\
\hline 1997-2009 & $\mathrm{J}$ & $\mathrm{U}$ & Poisoned & Santa Fé & Fandiño and Pautasso 2013 & 1 \\
\hline Unknown & $\mathrm{U}$ & $\mathrm{U}$ & Shooting & Santa Fé & Pautasso 2011g & 1 \\
\hline May 2011 & SA & M & Trapping/captive & Santiago del Estero & PCRAR $^{12}$ & 1 \\
\hline Unknown & SA & $\mathrm{U}$ & Trapping/captive & Tucumán & 13 & 1 \\
\hline Unknown & A & $\mathrm{U}$ & Trapping/captive & Unknown & PCRAR & 1 \\
\hline Unknown & A & $\mathrm{U}$ & Trapping/captive & Unknown & PCRAR $^{14}$ & 1 \\
\hline \multirow[t]{2}{*}{$\mathrm{U} / 2010$} & SA & $\mathrm{U}$ & Trapping/captive & Unknown & PCRAR & 1 \\
\hline & & & & & TOTAL & 83 \\
\hline
\end{tabular}

1. Subsecretariat of Environment, Directorate of Natural Resources, Province of Catamarca.

2. Roque Sáenz Peña Zoo.

3. Córdoba Zoo.

4. Guira Oga - National Fauna Direction.

5. CECARA (Center for the Study and Conservation of Birds of Prey in Argentina).

6. Secretariat of Environment, Province of La Rioja.

7. Directorate of Renewable Natural Resources, Province of Mendoza.

8. Bubalcó Zoo Park.

9. Subsecretariat of Environment and Environmental Policy, Province of San Juan.

10. Fauna Direction, San Juan.

11. Ministry of Legality and Institutional Relationships, Natural Resources Program, San Luis Province.

12. Direction of Flora, Fauna and Soil, Tucuman Province.

13. National University of Tucumán, Experimental Reserve "Horco Molle".

14. Aves Argentinas.

a. also in Yzurieta 1995.

b. also in De Lucca 1993.

c. also in Maceda et al. 2003.

d. also in Pereyra-Lobos 2004.

e. also in Chébez 2008.

f. also in De Lucca 1992.

g. also in Rodríguez et al. 2009. 